\title{
Maja Glušac \\ DOPUNE JEZIČNOM SAVJETU IVANA ZORIČIĆA O UPORABI NADNEVAKA
}

\author{
Pregledni rad \\ Review article
}

\section{UDK 811.163.42'367.7}

\begin{abstract}
U radu se propituju uzroci nepravilne uporabe nadnevaka u suvremenom hrvatskom jeziku. Istraživanje koje se temelji na građi Hrvatske jezične riznice Instituta za hrvatski jezik i jezikoslovlje pokazuje da se pojava imena mjeseca u kojem drugom padežu osim genitiva iza rednoga broja u nadnevku može povezati s jezičnim i stilskim određenjima. Ovisno o sintaktičkoj ulozi koju nadnevak može imati, a koja zahtijeva određeni padež, ime se mjeseca slaže s rednim brojem dana u rodu, broju i padežu. Osim nominativnih izraza koji imaju subjektnu ulogu ili ulogu predikatnoga imena, sročnost se imena mjeseca i rednoga broja javlja u akuzativnim i dativnim izrazima u objektnoj ulozi te u dativnim, akuzativnim i lokativnim izrazima u atributnoj ulozi. U nadnevcima koji imaju ulogu priložne oznake potvrđuje se zamjenjivanje besprijedložnih genitivnih izraza akuzativnima, a veliku ulogu u određenju padeža imena mjeseca imaju i prijedlozi - osobito u primjerima s instrumentalnim prijedlogom s, a učestalošću se izdvajaju i akuzativni izrazi s prijedlozima za i na te lokativni zrazi s prijedlogom o. Budući da se nepravilna uporaba nadnevaka većinom potvrđuje u novinskim tekstovima, može se odrediti kao obilježje publicističkoga stila.
\end{abstract}

Ključne riječi: nadnevak, sintaktičke uloge, sročnost, upravljanje

\section{Uvod}

Gramatike, pravopis i rječnici osnovni su jezični priručnici, ali jednako važnu ulogu u očuvanju hrvatskoga jezika i jezične kulture imaju jezični savjetnici. ${ }^{1}$ Među brojnim savjetnicima objavljenim u posljednjih dvadesetak godina dva su iz pera Ivana Zoričića: Hrvatski u praksi, objavljen 1998. godine i Tragom jezičnih nedoumica iz 2004. godine. Osnovno je obilježje Zoričićeva savjetničkog rada težnja za jednostavnošću, jasnoćom i sažetošću, što pak proizlazi iz upućenosti širem čitateljstvu. ${ }^{2}$

Polazeći od zapažanja Ivana Zoričića o učestalim nepravilnostima u uporabi izraza vremenskoga značenja, u ovome se radu posebna pozornost posvećuje pisanju nadnevaka. Prije razmatranja mogućih načina pisanja nadnevka, I. Zoričić (1998: 67-69) objašnjava razlike između istoznačnica datum i nadnevak: prvo, razlikuju se svojim podrijetlom (datum je primljenica iz latinskoga, a nadnevak je domaća tvorenica); drugo, razlikuju se mogućnostima izvođenja novih riječi (uz datum istoj porodici riječi pripadaju glagol datirati i pridjev datumski, dok imenica nadnevak nije tvorbeno plodna); i treće, razlikuju se uporabnom proširenošću (uporaba je imenice datum duboko ukorijenjena u hrvatskoj jezičnoj praksi, osobito u razgovornome,

1 Pregled hrvatskoga jezičnog savjetništva u 20. stoljeću donosi V. Rišner (2006.).

2 Za potrebe ovoga rada poslužio je prikaz Zoričićeva prvog jezičnog savjetnika Hrvatski u praksi Line Pliško (1999.) te osvrt na knjigu Tragom jezičnih nedoumica Ljiljane Kolenić (2004.). 
administrativnom i publicističkom stilu, a uporaba se nadnevka vezuje za "biranije stilove"). Nakon uvodnih razmatranja, navode se načini pisanja nadnevaka s obzirom na hrvatsku jezičnu tradiciju, pravopisna određenja i stilsku neutralnost. Nadalje, I. Zoričić upozorava na vrlo učestalo nepravilno pisanje nadnevaka s imenom mjeseca u nominativu ili akuzativu, a uz primjere navodi i kratko objašnjenje: "Približava se prvi svibnja, a ne prvi svibanj. - Danas je trideseti listopada, a ne trideseti listopad. - Pamtim petnaesti ožujka. Hrvatske slovnice takav padežni oblik nazivaju genitivom pripadnosti jer označuje kojem mjesecu pripada određeni dan." (Zoričić 1998: 69)

Potpuno navođenje nadnevka sadrži tri dijela: dan, mjesec i godinu, primjerice 1. siječnja 2001. U takvom se izrazu samo redni broj smatra datumskim genitivom, a ostalo su posvojni genitivi: označuje se kojemu mjesecu pripada određeni dan te kojoj godini pripada određeni mjesec. Naziv je mjeseca u genitivu u ulozi nesročnoga atributa uz izostavljenu imenicu dan - prvi (dan) (mjeseca) siječnja. Dakle, prvi je dan, dio mjeseca siječnja, siječanj je mjesec, dio 2001. godine.

Međutim, u skladu s metodološkim pristupom jezičnoj građi u Zoričićevu opisu izostaje podrobnije objašnjenje razloga zbog kojih dolazi do nepravilne uporabe imena mjeseca iza rednoga broja u nadnevku. Stoga će se ovim radom, koji je svojevrsna dopuna Zoričićevim zapažanjima, pokušati utvrditi jezični razlozi takve uporabe.

\section{Vremenski genitiv}

Vremenski genitiv najčešće označuje "vrijeme u koje se što zbiva" (Silić, Pranjković 2005: 202). Budući da se njime označuje samo dio vremena, svojstveno mu je lokalizacijsko značenje, ${ }^{3}$ tj. značenje vremenske točke, ${ }^{4}$ a uloga se vremenskoga genitiva određuje kao identifikacija vremenskog odsječka u kojemu se odvija ono što se izriče predikatom (Katičić 2002: 440). Međutim, besprijedložnim se genitivom mogu označiti i druga dva vremenska podznačenja, vremenska miera (npr. cijeloga dana) i ponavljanje (svakoga dana). ${ }^{5}$

Osobitost je besprijedložnih genitivnih izraza uporaba imenica vremenskoga značenja6 uz obveznu prisutnost atributa, a glavna je sintaktička uloga izricanje okolnosti vršenja glagolske radnje, tj. uloga priložne oznake. Međutim, kako prikazuju i navedeni Zoričićevi primjeri, nadnevak može imati i druge rečenične uloge, koje su pak obilježene određenim padežima

3 Besprijedložni se genitivni izrazi određuju pripadnošću statičkom tipu lokalizacijskig značenja kojim se označuje odsječak vremena bez ukazivanja na tijek vremena. Osim lokalizacijskiga značenja, razlikuje se i orijentacijsko značenje kojim se imenuje orijentacijska točka prema kojoj se određuje trenutak vršenja radnje, a to je značenje svojstveno samo prijedložnim izrazima (npr. pred zoru, oko ponoći). Vidi: M. Ivić (1955-1956: 165-168)".

4 Ovisno o tome na koja priložna pitanja odgovaraju izrazi vremenskoga značenja, razlikuju se tri podznačenja: izrazi sa značenjem vremenske točke odgovaraju na pitanje kada?, izrazi vremenske mjere odgovaraju na pitanje koliko dugo?, a izrazi sa značenjem ponavljanja odgovaraju na pitanje koliko često?. Usp.: Menac (1963: 263; 1989 : 88-91), Feleszko (1995: 62-63).

5 Značenje je vremenske mjere svojstveno besprijedložnome vremenskom akuzativu, što se potvrđuje gramatičkim opisima. "Ta dva gramatička rješenja nisu ipak sasvim istoznačna: genitivnim se izrazom utvrđuje vremenska jedinica u kojoj se odvija radnja predikata, a akuzativom se izriče trajanje radnje u vremenskoj jedinici." (Barić et al. 1999: 278) lako je uloga besprijedložnih akuzativnih izraza, kao i kod genitivnih izraza, identifikacija vremenskog odsječka, razlika je u tome što se u akuzativnim izrazima "vremenski odsječak promatra u svojemu trajanju" (Barić et al. 1997: 553).

Vidi još i: Katičić (2002: 90, 441), Raguž (1997: 139), Silić, Pranjković (2005: 223).

6 U besprijedložnim se genitivnim izrazima vremenskoga značenja ne mogu upotrebljavati imenice neodređenoga vremenskoga značenja (vrijeme, doba). Njihova je uporaba u genitivu vrlo učestala u atributnoj ulozi (npr. znanost onoga doba, književnost onoga vremena).

Imenice koje nemaju vremensko značenje upotrebljavaju se vrlo rijetko, a njihova se uporaba objašnjava činjenicom da su takvi pojmovi na vremenskoj crti toliko osobiti da mogu zamijeniti prave nazive vremenskih jedinica (Feleszko 1995: 62). Najčešće se upotrebljava imenica život, i to s atributom za oznaku sveukupnosti (cijeloga života). 
(npr. subjektna je uloga obilježena nominativom, a uloga izravnoga objekta akuzativom). Razlozi se nepravilne uporabe imena mjeseca u pisanju nadnevka stoga mogu pripisati gramatičkim vezama među sastavnicama sintagme, tj. sročnosti (ime je mjeseca u istom padežu kao i redni broj). Istraživanje će pak pokazati da se, ovisno o rečeničnoj ulozi, i ostali zavisni padeži (dativ, lokativ i instrumental) također mogu upotrebljavati umjesto pravilnoga genitivnog oblika imena mjeseca.

\section{Jezični savjeti o pisanju nadnevka}

Osim I. Zoričića, nepravilna je uporaba imena mjeseca iza rednoga broja zaokupljala pozornost mnogih drugih jezikoslovaca. O tome se podosta polemiziralo sredinom 20. stoljeća u časopisu Naš jezik,7 a problem je potaknuo Milan Rešetar koji izraze kao što je prvi siječanj smatra germanizmima. Pravilni su samo nadnevci u kojima je ime mjeseca u genitivu (npr. prvi siječnja) jer takav oblik, prema Rešetarovu mišljenju, pokazuje logički odnos između dijela (dana) i cjeline (mjeseca) te odgovara duhu našega jezika. Nasuprot tomu, P. Radivojević ispravnim smatra izraz prvi siječanj, a svoje razloge temelji na činjenici da je riječ o skraćenome izrazu prvi je, siječanj je. Nadalje, P. Radivojević tvrdi da je sveza prvi siječanj "tečnija, prirodnija i točnija", a izraz prvi siječnja osjeća se kao nešto "usiljeno i odveć pedantno". Na rečeno se nadovezuje i tumačenje F. llešića koji izraz prvi siječanj opravdava time da tako govori većina naroda, ali takvu uporabu ne smatra germanizmom nego primorskim izrazom koji je nastao pod talijanskim utjecajem.

Godine 1952. u ČasopisuJezik M. Hraste (1952: 121), potaknut pitanjem čitatelja iz Istre, objavljuje članak naslovljen Peti svibnja ili peti svibanj. Ponavljajući Rešetarove riječi, M. Hraste objašnjenju dodaje i značenjski kriterij: "Kad kažemo 'prvi ožujak', može se lako shvatiti, da se radi o prvom mjesecu ožujku za razliku od drugog mjeseca ožujka, na pr. Ovo je trideseti ožujak, koji doživljavam od rođenja." (Hraste 1952: 121) Nadalje, M. Hraste napominje da je uz narodne nazive mjeseci češći genitivni oblik imena mjeseca (prvi siječnja), a da se uz međunarodne nazive mjeseci češće upotrebljavaju izrazi s akuzativnim oblikom (prvi januar). Međutim, već i M. Hraste tada zaključuje da se pod utjecajem novinskoga jezika nepravilni oblici sve češće upotrebljavaju i prodiru u književni jezik.

Ljudevit Jonke 3. svibnja 1963. godine u Telegramu objavljuje članak naslovljen Nekoliko riječi i o Prvom maju (Jonke 2005: 154-155), u kojemu se osvrće na prijašnje polemike M. Rešetara, P. Radivojevića i F. llešića. Navodeći primjere Petra Preradovića i Marina Franičevića, Lj. Jonke napominje kako je tradicija pisanja nadnevka s genitivnim oblikom imena mjeseci "u Hrvata vrlo duga i vrlo živa" (Jonke 2005: 155), a problem dvostruke uporabe povezuje s normom: "Baš zato što nemamo jedne norme, nego se ukrštavaju različite upotrebe, književni nam jezik nije onako lako savladljiv kao što bi bio s jednom, književno provedenom normom." (Jonke 2005: 155)

Razloge dvostruke uporabe A. Menac (1963.) povezuje s gramatičkim vezama među sastavnicama sintagme te smatra da se izraz prvoga siječnja može shvatiti kao sročnost (prvi siječanj, prvim siječnjem) ili kao upravljanje (prvi siječnja, prvim siječnja) te zaključuje: "Jedan je oblik, dakle, pružao mogućnost za dvojako tumačenje pa je u nekim našim krajevima shvaćen na jedan, a u drugima na drugi način." (Menac 1963: 268-269)

7 Navedene se bilješke o polemici u časopisu Naš jezik preuzimaju iz rada Antice Menac (1963.) u kojemu se donosi i bibliografija spomenutih rasprava:

Rešetar, M., "Prvi januara ili prvi januar", Naš jezik, II, 3, str. 68.

Radivojević, P., "Prvi januara ili prvi januar", Naš jezik, II, 4, str. 114.

Rešetar, M., "Germanizam u brojenju", Našjezik, II, 6, str. 169.

Ilešić, F., "Germanizam u brojenju?", Našjezik, II, 8, str. 228.

Georgijević, S., "Još o 'prvi januara"', Naš jezik, III, 6, str. 80. 
Učestalost se obaju načina pisanja nadnevaka u hrvatskome jeziku odrazila na drukčije tumačenje te pojave u Jezičnome savjetniku s gramatikom (Pavešić (ur.) 1971). Osim nadnevka s imenom mjeseca u genitivu, autori savjetnika napominju da uz redni broj dana "ime mjeseca može biti u istom padežu u kojem je broj te se čini kao da se redni broj odnosi na mjesec: 'Danas je osmi prosinac. Dopust mi počinje s petim svibnjem.'" (Pavešić (ur.) 1971: 148) Nadalje, objašnjavaju da "kako u godini ima samo po jedan mjesec istoga imena, ni ovaj način ne dovodi do nejasnoća o kojem se mjesecu radi, a veza rednog broja i imena mjeseca može se uzeti kao ime dana, što je već sasvim obično za neke spomen-dane: Prvi maj, osmi mart." Autori na kraju izrijekom kazuju da se "oba [se] načina izricanja datuma mogu prihvatiti i u književnom jeziku." (Pavešić (ur.) 1971: 148) Jedini je to jezični savjetnik u kojemu se nadnevci s imenom mjeseca u kojem drugom padežu osim genitiva smatraju pravilnima.

O učestaloj uporabi nepravilnih oblika nadnevaka svjedoče i brojne napomene u suvremenim jezičnim savjetnicima. O tome, osim I. Zoričića (1998: 69), pišu još i F. Tanocki (1994: 114), M. Dulčić (1997: 71), A. Frančić et al. (2005: 133) te M. Matković (2006: 87). Savjeti se o pravilnome pisanju i izgovaranju nadnevka mogu pronaći i na mrežnim stranicama Instituta za hrvatski jezik i jezikoslovlje.

\section{Nepravilna uporaba nadnevka u hrvatskom književnom jeziku}

U nastavku se rada na primjerima iz Hrvatske jezične riznice Instituta za hrvatski jezik i jezikoslovlje propituju učestalost i okolnosti nepravilne uporabe nadnevaka. Pojava se imena mjeseca iza rednoga broja u kojem drugom padežu osim genitiva dovodi u vezu sa sintaktičkim ulogama koje nadnevak (kao cjelina) može imati. Pri pregledavanju su se Rizničina korpusa u obzir uzimali samo nadnevci u kojima iza rednoga broja slijede hrvatski nazivi za mjesece (siječanj, veljača,...). Ukupno je zabilježeno 475 primjera nepravilne uporabe, od čega je čak 451 primjer iz publicističkoga stila. Brojnošću se izdvajaju izjednačeni nominativni/akuzativni (134) te instrumentalni izrazi (132), a zatim slijede nominativni (96) i akuzativni izrazi (76), dok su najmanje zastupljeni lokativni (24) i dativni izrazi (13).

\subsection{Nominativni/akuzativni izrazi}

Osobitost je publicističkoga stila izdvajanje mjesta i vremena radnje na samome početku novinskoga članka, a u takvoj se vremenskoj lokalizaciji vrlo često mogu naći izjednačeni nominativni/akuzativni oblici nadnevaka. Genitivni i akuzativni izrazi sa značenjem vremenske točke vrlo su slični (u obama je obvezna uporaba atributa uz imenice vremenskoga značenja) te su stoga i međusobno zamjenjivi::

ZAGREB, 12. siječanj (Vj20010113), BERLIN, 11. ožujak (Vj20010312), LOS ANGELES, 22. travanj (Vj20040423), RIM, 25. svibanj (Vj20010526), PARIZ, 1. lipanj (Vj20040602), ZAGREB, 17. srpanj (Vj20010718), SPLIT, 5. kolovoz (Vj20000806), TEL AVIV, 28. rujan (Vj20020929), TOKIO, 2. listopad (Vj20031003), JOHANNESBURG, 13. studeni (Vj20011114), SVETI KRIŽ ZAČRETJE, 3. prosinac (Vj20021204)

Padež se imena mjeseca, tj. nominativ, u ulozi priložne oznake pouzdano može odrediti samo s imenom drugoga mjeseca - veljače:

ZABOK, 10. veljača (Vj20020211), ZAGREB, 15. veljača (Vj20010216)

8 Genitivni se izrazi vremenskoga značenja ne mogu zamijeniti akuzativnima kada je imenica pobliže određena nesročnim atributom: npr. Dogodilo se to mjeseca siječnja - *mjesec siječanj. 
Vremenska se lokalizacija nalazi i u zagradama u tekstu;

Mate Parlov (Split, 16. studeni 1948. - Pula, 29. srpanj 2008.) bio je genijalni boksač. (002893), U tijeku su pregovori između Hrvatske radio televizije i Hajduka oko prijenosa s prve utakmice u Splitu (23. srpanj),... (Vj20000713)

kao i u navođenju literature:

M. Lehpamer, Radio i vrednosno sudjelovanje u suvremenoj kulturi, Republika, 5. svibanj 1975. str. 506. (Stjepko Težak, 2002., Metodika nastave filma na općeobrazovnoj razini, Školska knjiga, Zagreb),

To je istaknuto u članku "GESLO: bez samostalne hrvatske države nema hrvatskog naroda", Nezavisna hrvatska država (Berlin), br. 1., 1. lipanj 1933., str. 1. (Mario Jareb, 2006., Ustaško-domobranski pokret od nastanka do travnja 1941. godine, Školska knjiga, Zagreb)

Takvi se izrazi, sasvim neočekivano, potvrđuju i s genitivnim prijedlozima od i do:

... jamče da će do 15. kolovoz biti u Rimu. (Vj20000806), ... i nude mu bezrezervnu podršku uoči europskog "final foura" u Dubrovniku (od 25. do 27. svibanj). (Vj20010505), Prošli je vikend u odnosu na isti vikend lani (od 19. do 21. kolovoz 2005.) zabilježio povećanje od 2,47 posto ... (Vj20060822)

\subsection{Nominativni izrazi}

Nominativ je padež rečeničnoga subjekta pa se stoga i nominativni oblik imena mjeseca iza rednoga broja vrlo često upotrebljava u nadnevcima koji su u subjektnoj ulozi:

No i 1. siječanj 2005. već je daleko za nama (Vj20050228), "Prvi listopad ostavit će ljude u Darfuru bez zaštite i humanitaraca koji će napustiti to područje" upozorio je slavni glumac. (Vj20060916), Novcima je bio obilježen i 22. prosinac 1992. godine. (Vj20031221)

Takvi se primjeri mogu pronaći i u književnim djelima druge polovice 19. stoljeća:

Dan po dan - dojde i prvi listopad. (Nikola Tordinac, 1890., Odabrane crtice i pripoviesti, Matica hrvatska, Zagreb)

Osim osnovne, subjektne uloge, nominativni se oblik javlja i u ulozi predikatnoga imena:

Trebala bi pomoći u izboru najpovoljnije lokacije, a rok za završetak je 30. studeni 2004. (Vj20030820), Krajnji rok početka gradnje je 15. svibanj ove godine. (Vj20070120)

Nominativni se oblik nadnevka javlja i u nazivima institucija, organizacija, tvrtki i sl.:

... predložit ću i mojim prijateljima iz "Udruge 11. siječanj 1972." (Vj20040425), U Kiseljaku zasigurno nije bio ni Elvedin Kermo, predsjednik udruženja žrtava rata "16. travanj 1994." iz Ahmića,... (Vj20040806), ... apostrofirajući dozvoljeni pokolj u Srebrenici radom "11. srpanj 1995." koji je ustvari tekst Deklaracije o Srebrenici kao zaštićenoj zoni, ... (Vj20020728) 


\subsection{Dativni izrazi}

U hrvatskom se književnom jeziku vrijeme ne može izricati besprijedložnim dativnim izrazima jer je osnovno značenje dativa negranična usmjerenost, što znači da odnos između dvaju predmeta pretpostavlja približavanje jednoga predmeta drugomu, i to tako da jedan predmet služi kao orijentir drugomu. Iz toga su se razvila značenja cilja, davanja, pripadanja, namjene i sl. Stoga se dativni izrazi ne upotrebljavaju u ulozi priložne oznake vremena. Međutim, građa potvrđuje i takvu uporabu, a može se pretpostaviti da je riječ o slučajnoj, nenamjernoj autorovoj pogrješci (tipfeleru):

VARAŽDIN, 23. ožujku (Vj20010324), Hoće li EU, odnosno Task Force još jednom procjenjivati suradnju Hrvatske s Haaškim sudom prije sastanka ministara vanjskih poslova EU-a 18. srpnju? (Vj20050630), Nakon što je 19. lipnju pokrenut stečaj u "Karbonu", dio radnika još uvijek nije dobio plaće (Vj20001114)

Besprijedložni se dativni izrazi javljaju u objektnoj ulozi te se njima označuju i osnovna dativna značenja - usmjerenost i namjena:

Po njegovim sljedećim potezima vidjet će se, što smo bliže 24. travnju, kad počinje kampanja, koliko će i hoće li biti neutralan. (Vj20050414), Idući u susret 31. svibnju, Danu nepušača, pitamo se: Pušiti ili ne pušiti? (Vj20020526), ... te je večernje vijesti s Danom Ratherom, jednim od najuglednijih tv komentatora, posvetio 11. rujnu. (Vj20020912)

Manje se upotrebljavaju besprijedložni dativni izrazi u ulozi nesročnoga atributa, što se potvrđuje primjerom iz jezika četrdesetih godina 20. st.:

U doba reformacije nastaje na mnogo strana povratak 1. siječnju kao početku godine (Milovan Gavazzi, 1939., Godina dana hrvatskih narodnih običaja, Hrvatsko etnološko društvo, Zagreb)

\subsection{Akuzativni izrazi}

Zamjenjivanje genitivnoga oblika imena mjeseca akuzativnim vrlo se često potvrđuje u prijedložnim izrazima. Nadnevak se u ulozi priložne oznake vremena vrlo često javlja u akuzativnim izrazima s prijedlogom za, i rjeđe s prijedlogom na. U većini je takvih primjera nadnevak u ulozi dopune glagola:

... da je primjena pojedinih odredbi izmijenjenog zakona o mirovinskom osiguranju odgođena za 1. siječanj iduće godine. (Vj20021218), Sljedeća rasprava zakazana je za 11. svibanj. (Vj20010303) ... a uzvrat je predviđen za 3. ili 4. kolovoz u Splitu. (Vj20050627)

Vladajejošjednom -na 31. prosinac 2002. - produljila rokove za predaju oružja ... (Vj20020125), ... Vlada je odgodila početak nove nastavne godine sa 4. na 11. rujan, (Vj20000910)

Osim u ulozi priložne oznake, akuzativni se oblici imena mjeseci učestalo javljaju i u nadnevcima u objektnoj ulozi:

Oni koji ne shvaćaju i ne prihvaćaju 3. siječanj 2000. kao dan koji svakako nije novo brojanje vremena, (Vj20000920), Mnogi Zagrepčani iskoristit će produženi vikend i 1. svibanj dočekati u nekoj od popularnih europskih metropola. (Vj20070424), U svom govoru pred 750 vojnika, pilota i časnika, predsjednikje spomenuo 11. rujan šest puta. (Vj20050630) 
U ulozi se nesročnoga atributa akuzativni oblici najčešće javljaju s prijedlogom na, a nešto rjeđe s prijedlogom za:

Objasnio da je u noći na 3. prosinac, prije kobnoga jutra, prijevoz repe obavljalo tridesetak kamiona ... (Vj20020225), Čekanje na 15. travanj, kada su ministri SLS-a namjeravali dati ostavke, značilo bi samo produljenje nesigurnosti .... (Vj20000404)

... a tu utakmicu igramo samo kao provjeru za 29. ožujak i dvoboj protiv Belgije?(Vj20021024), Mnogi, međutim, vjeruju da je to bila odmazda za 11. rujan 2001. godine, koji se možda može vezati uz prethodnu izolaciju Iraka, (Vj20050725)

\subsection{Lokativni izrazi}

Lokativni su izrazi najučestaliji s prijedlogom o, nešto su rjeđi s prijedlogom na, a u obama se izrazima upotrebljavaju kao dopune glagolima:

Bin Ladenovi suradnici prvi put progovorili o 11. rujnu (Vj20020909), Nagađa se o 16. ili 23. studenome, no građanin predsjednik s Pantovčaka, kao jedini mjerodavan za to, nije se još oglasio. (Vj20030919)

... gradonačelnik je nedavno inzistirao na 5. rujnu kao završetku radova (Vj20010818)

Prijedložni se izrazi s prijedlogom o, osim u ulozi dopune glagolima govorenja i mišljenja, mogu naći u atributnoj ulozi kao dopuna odglagolnim imenicama slična značenja:

No, priča o 22. prosincu tu ni izbliza nije zgotovljena. (Vj20031221), Odbacujući nagađanja o 1. siječnju iduće godine, kao datumu mogućeg ukidanja vojnog roka, ministar je kazao kako je taj termin bio definiran samo zbog lakšeg vođenja polemike. (Vj20010703) ... da se na osnovi nje može dobiti ma samo i približna slika o 21. lipnju. (Vaso Bogdanov, 1949., Društvene i političke borbe u Hrvatskoj 1848/49, JAZU, Zagreb)

S genitivnim se prijedlozima od i do potvrđuju i lokativni oblici imena mjeseca u nadnevcima u ulozi priložne oznake:

Izložba akademika Ivana Kožarića "Fotografija" otvorena je u Malom salonu na Korzu od 2. do 28. kolovozu. (Vj20050804), No vjeruje se da ni Amerikanci neće lako odustati od pokušaja da saznaju istinu od 11. rujnu 2001. (Vj20020916)9

\subsection{Instrumentalni izrazi}

Instrumentalni se oblici imena mjeseci potvrđuju samo u ulozi priložne oznake vremena. Vrlo se rijetko nadnevak javlja u besprijedložnome instrumentalnom izrazu:10

9 U posljednjem se primjeru može pretpostaviti da se prijedlog od javlja umjesto prijedloga o kojim bi se uveo lokativni oblik (istina o 11. rujnu).

10 Uporaba besprijedložnoga instrumentala imenice vrijeme nije normativno preporučljiva te se preporučuje prijedložni instrumental s prijedlogom s (s vremenom). Jedan je od razloga tomu i sintaktička (i značenjska) dvosmislenost besprijedložnih izraza - mogu se shvatiti kao objekt ili kao priložna oznaka (vremena, sredstva, načina ili uzroka). Navedeno se može primijeniti i u navedenim primjerima nadnevaka. Usp. Raguž (1997: 154), Dulčić (1997: 368), Težak, Babić (2005: 301), Silić, Pranjković (2005: 236). 
Danci rekoše da je 20. stoljeće počelo Prvim svjetskim ratom, a završava danom velikog proširenja, 12. prosincem ove godine. (Vj20020704), Prvim travnjem god. 1849. budem bez moga zahtievanja premješten po svietlom banu k prvoj banskoj regimenti. (Petar Preradović, 1890., Izabrane pjesme, Matica hrvatska, Zagreb)

Prijedložni su instrumentalni izrazi s prijedlogom s vrlo učestali. Njihova je osobitost u tome što označuju istodobnost, odnosno vrijeme radnje koje se odvija istodobno s vremenom označenim instrumentalom. U njima se, uz vremensko značenje, zadržavaju i osnovna instrumentalna značenja - značenja sredstva i društva:

Prošle je godine ta tvrtka ostvarila prihode i dobit prije poreza u iznosu od 115,8 milijuna eura, odnosno 90 milijuna eura, te je sa 1. siječnjem ove godine imala neto imovinu u iznosu od 40,5 milijuna eura. (Vj20010615), S 1. travnjem ukidaju se carine na sljedeće proizvode ... $(\mathrm{Vj} 20010223)^{11}$

Uporaba je prijedložnoga instrumentalnog izraza s prijedlogom pod zabilježena samo u dvama primjerima Augusta Šenoe, dok se u suvremenim tekstovima ne upotrebljava:

Pod 10. veljačom 1578. zabilježio sudac Teletić u svojim računima, da je od Matije Vernića kupio vola, ... (August Šenoa, Zlatarevo zlato), U računima suca Teletića ubilježeno je pod 28. srpnjem 1578, da je gradski sudac dao Petru Županu, Ivanu Jakopoviću i Marku literatu, (...), za putni trošak 40 dinara. (August Šenoa, Zlatarevo zlato)

\section{Zaključno}

Uzmemo li u obzir primjere u kojima se nepravilno napisani nadnevci mogu smatrati nenamjernom, slučajnom pogrješkom (npr. do 15. kolovoz, do 28. kolovozu, 23. ožujku), sa sigurnošću možemo govoriti o sasvim nepoželjnom obilježju.

Međutim, razlozi se uporabe nepravilnih oblika imena mjeseca iza rednoga broja u pisanju nadnevaka mogu tražiti i u samome jeziku, tj. u gramatičkoj vezi između rednoga broja dana i imena mjeseca. Ovisno o sintaktičkoj ulozi koju nadnevak može imati, a koja zahtijeva određeni padež, ime se mjeseca slaže s rednim brojem u rodu, broju i padežu. Uzmemo li u obzir učestalost takvih primjera u publicističkom stilu, kao i činjenicu da bi ih upotrijebio i velik broj govornika hrvatskoga jezika, moglo bi se zaključiti da je tu odstupanje od norme suvremenoga hrvatskog standardnog jezika manje pa bi se možda moglo raspravljati i o njihovoj "rubnoj" prihvatljivosti.

U primjeru Druga stvar, ono što bih volio jest da 1. prosinca znam što mi nosi 1. siječanj. (Vj20040404) samo je prvi nadnevak, koji je u ulozi priložne oznake vremena, ispravno napisan. Vodimo li se mišlju da su u svijesti autora navedenoga primjera dijelovi sintagme povezani na temelju sročnosti imena mjeseca i rednoga broja (a ne upravljanja pri kojemu redni broj, u kojemu god padežu bio, zahtijeva genitiv imena mjeseca), ime se mjeseca slaže s genitivom rednoga broja (prvoga prosinca) jer se vremenska točka najčešće izriče genitivnim izrazima. Pri tome se dakako velika uloga mora pripisati i jezičnoj ekonomiji. Potvrda je tezi o sročnosti drugi nadnevak u subjektnoj ulozi u kojemu se ime mjeseca slaže s rednim brojem u nominativu, padežu rečeničnoga subjekta ( ${ }^{*}$ prvi siječanj).

Osim nominativnih izraza koji imaju subjektnu ulogu ili ulogu predikatnoga imena, sročnost

11 Potvrđuju se i nepravilni oblici prijedložnoga instrumentala imena mjeseca s prijedlogom s u kojima se ne provodi prijeglas: lako se naknada počela obračunavati s 1. travnjom, još se točno ne zna ... (Vj20040424), ... čiji su dugovi zaključeni s 30. lipnjom 2000. godine. (Vj20010330), Inače je rok "Njavrinih kredita" istekao sa 31. srpnjom,... (Vj20000812). 
se imena mjeseca i rednoga broja javlja i u akuzativnim i dativnim izrazima u objektnoj ulozi te u akuzativnim, dativnim i lokativnim izrazima u atributnoj ulozi. Budući da nadnevci označuju točno vrijeme predikatne radnje, najveći ih je broj u ulozi priložne oznake pa građa potvrđuje vrlo velik broj nadnevaka u kojima je ime mjeseca u izjednačenom nominativnom/akuzativnom obliku. Akuzativni se izrazi pri tome mogu objasniti sročnošću kao i zamjenom genitiva vremenske točke akuzativom istoga značenja (usp. toga dana/taj dan - prvoga siječnja/prvi siječanj). Veliku ulogu u određenju padeža imena mjeseca iza rednoga broja imaju i prijedlozi - osobito je to prisutno u izrazima s instrumentalnim prijedlogom s, a brojnošću se primjera izdvajaju i akuzativni izrazi s prijedlozima za i na te lokativni izrazi s prijedlogom o.

Međutim, u promatranoj su građi učestali i primjeri u kojima se u istoj rečenici mogu pronaći dvostrukosti u pisanju nadnevka:

Dvadeset i šest dana prije početka Olimpijskih igara u Sydneyu (od 15. rujna do 1. listopad), Hrvatski se olimpijski odbor suočio s poteškoćama ... (Vj20000820), Tako je za 9. srpanj najavljeno drugo izdanje Velebitskog trekkinga, a za 11. rujna drugo izdanje Urban Challenge utrke. (Vj20040507), Kao mogući datum tog vojnog pohoda, pod vodstvom Amerikanaca, predviđa se 28. veljače ili 1. ožujak. (Vj20030206), ... Agencija će vjerojatno donijeti poseban akt o tome, a mogući su datumi 1. listopada ili 1. studeni. (Vj20010620)

Time se pokazuje kako pojedini autori novinskih članaka imaju vrlo "nemaran" odnos prema normi suvremenoga hrvatskoga jezika. Budući da je jedna od osobitosti publicističkoga stila upućenost brojnim primateljima, učestalost je nepravilno napisanih nadnevaka teško opravdati. Ne iznenađuje stoga stalna prisutnost jezičnih savjeta o tome kako pisati, ali i čitati,12 nadnevke.

12 Uporaba je imena mjeseca u kojem drugom padežu osim genitiva vrlo učestala i u razgovornom stilu.

\section{POPIS LITERATURE}

\section{BARIĆ ET AL. 1997}

Eugenija Barić, Mijo Lončarić, Dragica Malić, Slavko Pavešić, Mirko Peti, Vesna Zečević, Marija Znika, Hrvatska gramatika, Školska knjiga, Zagreb, 1997.

\section{DULČIĆ 1997}

Govorimo hrvatski, jezični savjeti, priredio Mihovil Dulčić, Hrvatski radio i Naklada Naprijed d.d., Zagreb 1997.

\section{FELESZKO 1995}

Kazimierz Feleszko, Značenje i sintaksa srpskohrvatskog genitiva, prijevod Gordane Jovanović, Matica srpska, 1995.

\section{FRANČIĆ ET AL. 2005}

Anđela Frančić, Lana Hudeček, Milica Mihaljević, Normativnost i višefunkcionalnost u hrvatskome standardnom jeziku, Hrvatska sveučilišna naklada, Zagreb 2005.

\section{HRASTE 1952}

Mate Hraste, "Peti svibnja ili peti svibanj", Jezik, I, br. 4, 1952., str. 121

\section{IVIĆ 1955-1965}

Milka Ivić, "Iz problematike padežnih vremenskih konstrukcija", u: Južnoslovenski filolog, XXI, 1955.-1956., str. 165-214

\section{JONKE 2005}

Ljudevit Jonke, O hrvatskome jeziku, Pergamena, Zagreb 2005.

\section{KATIČIĆ 2002}

Radoslav Katičić, Sintaksa hrvatskoga književnog jezika, HAZU, Nakladni zavod Globus, Zagreb 2002.

\section{KOLENIĆ 2004}

Ljiljana Kolenić, "Hrvatske jezične nedoumice, Ivan Zoričić, Tragom jezičnih nedoumica, Zavičajna naklada "Žakan Juri", Pula, 2004.", Život i 
škola: časopis za teoriju i praksu odgoja i obrazovanja, I, br. 12, 2004., str. 155-157

\section{MATKOVIĆ 2006}

Maja Matković, Jezični savjetnik - iz prakse za praksu, Škorpion, Zagreb 2006.

\section{MENAC 1963}

Antica Menac, "Datumski genitiv u hrvatskosrpskom i ruskom jeziku", u: Ivšićev zbornik, Zagreb 1963., str. 263-270

\section{MENAC 1989}

Antica Menac, "Upotreba i značenje padeža bez prijedloga u suvremenom ruskom i hrvatskom književnom jeziku", u: Rad JAZU, knjiga 427, Zagreb 1989., str. 71-126

\section{PAVEŠIĆ (UR.) 1971}

Vida Barac-Grum, Dragica Malić, Slavko Pavešić (ur.), Zlatko Vince, Jezični savjetnik s gramatikom, Matica hrvatska, Zagreb 1971.

\section{PLIŠKO 1999}

Lina Pliško, "Nov prinos razvoju jezične kulture, Ivan Zoričić, Hrvatski u praksi", Fluminensia, Xl, br. 1-2, 1999., str. 206-209

\section{RAGUŽ 1997}

Dragutin Raguž, Praktična hrvatska gramatika, Medicinska naklada, Zagreb 1997.

\section{RIŠNER 2006.}

Vlasta Rišner, "Hrvatsko jezično savjetništvo u 20. stoljeću", u: Hrvatski jezik u XX. stoljeću, Matica Hrvatska, Zagreb 2006., str. 367-393

\section{SILIĆ, PRANJKOVIĆ 2005}

Josip Silić, Ivo Pranjković, Gramatika hrvatskoga jezika za gimnazije i visoka učilišta, Školska knjiga, Zagreb 2005.

\section{TANOCKI 1994}

Franjo Tanocki, Hrvatska riječ, jezični priručnik, Matica hrvatska, Osijek 1994.

\section{TEŽAK, BABIĆ 2005}

Stjepko Težak, Stjepan Babić, 2005. Gramatika hrvatskoga jezika, Školska knjiga, Zagreb 2005.

\section{ZORIČIĆ 1998}

Ivan Zoričić, Hrvatski u praksi, Zavičajna naklada "Žakan Juri", Pula 1998.

\section{SUPPLEMENTS TO IVAN ZORIČIĆ'S LANGUAGE USAGE ADVICE}

The paper questions the causes of irregular usage of dates in contemporary standard Croatian language. The research based on the material from Croatian Language Repository of the Institute of Croatian Language and Linguistics shows that an appearance of a month name in a case other than genitive after the ordinal number in a date can be linked to features of language and style. Depending on the syntactic role that a date can have, which demands a specific case, the month name agrees with the ordinal number of the day in gender, number and case. Besides nominal phrases in the role of subject or predicate nominative, the agreement between the month name and the ordinal number appears in accusative and dative phrases in the role of object and in dative, accusative and locative phrases in attributive role. In dates having the adverbial role, replacement of non-prepositional genitive phrases by accusative ones has been confirmed. Prepositions also have a big role in determining the case of a month name - especially in examples with the instrumental preposition s. Accusative phrases with the prepositions za and $n a$ and locative phrases with the preposition o are also very frequent. Since irregular usage of dates is mostly found in newspaper texts, it can be defined as a feature of the journalistic style.

Key words: date, syntactic roles, agreement, government 